\title{
Breast self-exams in a group of women participating in mammography screening
}

\author{
Elżbieta Garwacka-Czachor, Adam Maciejczyk, Marek Bębenek
}

Introduction. A key role in the struggle against breast cancer is played by secondary prevention, which includes breast self-exams, clinical tests, and mammography screening. The purpose of the study was to analyze the impact of age, education, and selected breast cancer risk factors on the frequency with which women participating in the mammography screening program perform breast self-exams.

Material and methods. The study group consisted of 32,626 women aged 50-69, enrolled in the Early Breast Cancer Detection Program in Lower Silesia between January 2007 and 2011. The study was conducted by means of a diagnostic survey and the frequency of breast self-exams was analyzed as a function of age, education, and selected risk factors. Results. Only $14 \%$ of respondents, mostly younger and better educated, reported that they examined their breasts regularly every month. Exposure to risk factors had a negligible impact on the frequency of self-exams.

Conclusions. Younger and better educated women were more likely to perform breast self-exams. Risk factors, such as a family history of breast cancer and the prolonged use of hormonal medication, did not have a significant impact on self-exam frequency. Monthly self-exams were more often reported by women suffering from breast-related ailments, probably because of the associated experience of pain and discomfort.

NOWOTWORY J Oncol 2016; 66, 6: 445-449

Key words: breast cancer, breast self-exam, mammography screening, prevention

\section{Introduction}

Epidemiological data suggest that the incidence of breast cancer continues to be on the rise. In Poland, the disease is characterized by medium morbidity and moderate mortality rates [1]. In 2013, it was diagnosed in 17,142 women, representing $21.9 \%$ of all detected cancers. Second only to lung cancer as the leading cause of death among women, the disease accounted for as many as 5816 deaths, i.e. $13.9 \%$ of total female cancer-related mortality in 2013 [2]. As the most common cancer to affect women, it represents a major public health concern all around the globe, as well as in Poland. A key role in the struggle against the disease is played by prophylaxis, and an essential element of the latter is secondary prevention, i.e. early cancer detection with a view to reducing related mortality rates $[3,4]$.

Prevention should be accompanied by adequate health education designed to raise health awareness in society.
The latter is a complex cognitive structure that shapes and determines health behaviors among people, and crucially depends on the ability to perceive the warning signs of health risks, the knowledge of health and disease acquired from various sources, and the place of health in the human hierarchy of values [5]. The minimum cancer awareness that needs to be imparted to the female general public consists in the ability to recognize early symptoms of breast cancer. However, it is equally crucial to encourage an alert attitude and encourage women to take up conscious healthpromoting behaviors, such as performing regular breast self-exams and seeking medical help whenever any alarming symptoms show up [6].

Health behaviors can be defined as all the actions in the daily life of a person that affect his/her health. They represent the practical application of the knowledge of health and disease and constitute the product of individual 
choice. Health behaviors can be either health-promoting or health-defeating [7]. Actions that benefit women's health include, for instance, breast self-exams, mammography, and participation in screening tests [8]. Contrary to the view expressed by the United States Preventive Services Task Force (US PSTF), which holds that self-exams play a rather negligible role in the reduction of breast-cancer mortality, the practice constitutes an important element in the secondary prevention of the disease [9]. Learning how to examine their own breasts on a regular basis motivates women to take better care of their health, and significantly contributes to raising female health awareness $[10,11]$.

The purpose of the study was to analyze the impact of age, education, and selected breast-cancer risk factors on the frequency with which women participating in mammography screening tests perform breast self-exams.

\section{Material and methods}

The study group consisted of 32,626 women aged 50-69 , signed up for mammography screening at the Lower Silesian Oncology Center in Wrocław in the framework of the Population-Based Early Breast Cancer Detection Program. The study was conducted between January 2007 and December 2011 and used a dedicated questionnaire previously designed for the program [12].

Data was collected prospectively by the Lower Silesian Voivodeship Coordinating Center for the Early Breast Cancer Detection Program at the Lower Silesian Oncology Center and stored in the Computer-Based Prevention Monitoring System.

The frequency of self-exams ("every month", "sometimes", "never") was analyzed as a function of the age and education of respondents enrolled in the early detection program. Women between the ages of 50 and 69 were grouped into 5-year age brackets. Their level of education was described on a scale ranging from incomplete primary to a university degree. In addition, self-exam frequency was studied in terms of selected risk factors (such as a family history of breast cancer, the use of hormonal medication for more than 5 years) and the presence of alarming symptoms and breast lesions (pain, lumps, nipple discharge, breast skin lesions).

\section{Statistical analysis}

Regression analysis was used to estimate the impact of age, education, and selected risk factors on the frequency of self-exams. All calculations were performed with Microsoft Excel.

\section{Results}

\section{Frequency of breast self-exams as a function of age and education}

Monthly self-exams were reported by 4512 (14\%) women; 5861 (18\%) declared that they never examined their breasts, and the remaining $22,253(68 \%)$ said they did it sometimes.

The 50-54 age bracket was set as the point of reference. Successive age groups varied significantly with respect to the number of women who responded "once a month", "sometimes", or "never" when asked how often they performed breast self-exams. The proportion of women who reported a monthly frequency decreased in successive age groups (55-59, 60-64, and 65-69) by, respectively, 0.8\%, $1.2 \%$, and $1.6 \%$ as compared to the baseline. The largest difference in the "sometimes" group (1.9\%) was observed in the 65 to 69 age bracket. Age was also related to how likely a woman was to give up self-exams altogether; the percentage of respondents who declared they never examined their breasts significantly increased with age (Tab. I, Fig. 1).

The proportion of women who did examine their breasts on a regular basis showed a linear increase from a meager $7.2 \%$ in the group of respondents with incomplete primary education to $14.3 \%$ in the group of university graduates. Conversely, the proportion of women who did not examine their breasts at all dropped from c. $30 \%$ in the group of respondents with primary education to just $15 \%$ in the group of women who had graduated from secondary school (Tab. II).

Table I. Number and percentage of women who perform regular breast self-exams as a function of age

\begin{tabular}{|c|c|c|c|c|c|}
\hline \multirow[t]{2}{*}{ Frequency } & & \multicolumn{4}{|c|}{ Age (years) } \\
\hline & & $50-54$ & $55-59$ & $60-64$ & $65-69$ \\
\hline \multirow{3}{*}{$\begin{array}{l}\text { Every month } \\
n=4512\end{array}$} & Number & 1397 & 1367 & 1095 & 653 \\
\hline & Percentage & 14.6 & 13.8 & 13.4 & 13.0 \\
\hline & Difference, \% & 0 & -0.8 & -1.2 & -1.6 \\
\hline \multirow{3}{*}{$\begin{array}{l}\text { Sometimes } \\
n=22253\end{array}$} & Number & 6538 & 6814 & 5553 & 3348 \\
\hline & Percentage & 68.5 & 68.9 & 68.0 & 66.6 \\
\hline & Difference, \% & 0 & 0.4 & -0.5 & -1.9 \\
\hline \multirow{3}{*}{$\begin{array}{l}\text { Never } \\
n=5861\end{array}$} & Number & 1611 & 1708 & 1519 & 1023 \\
\hline & Percentage & 16.9 & 17.3 & 18.6 & 20.4 \\
\hline & Difference, \% & 0 & 0.4 & 1.7 & 3.5 \\
\hline
\end{tabular}




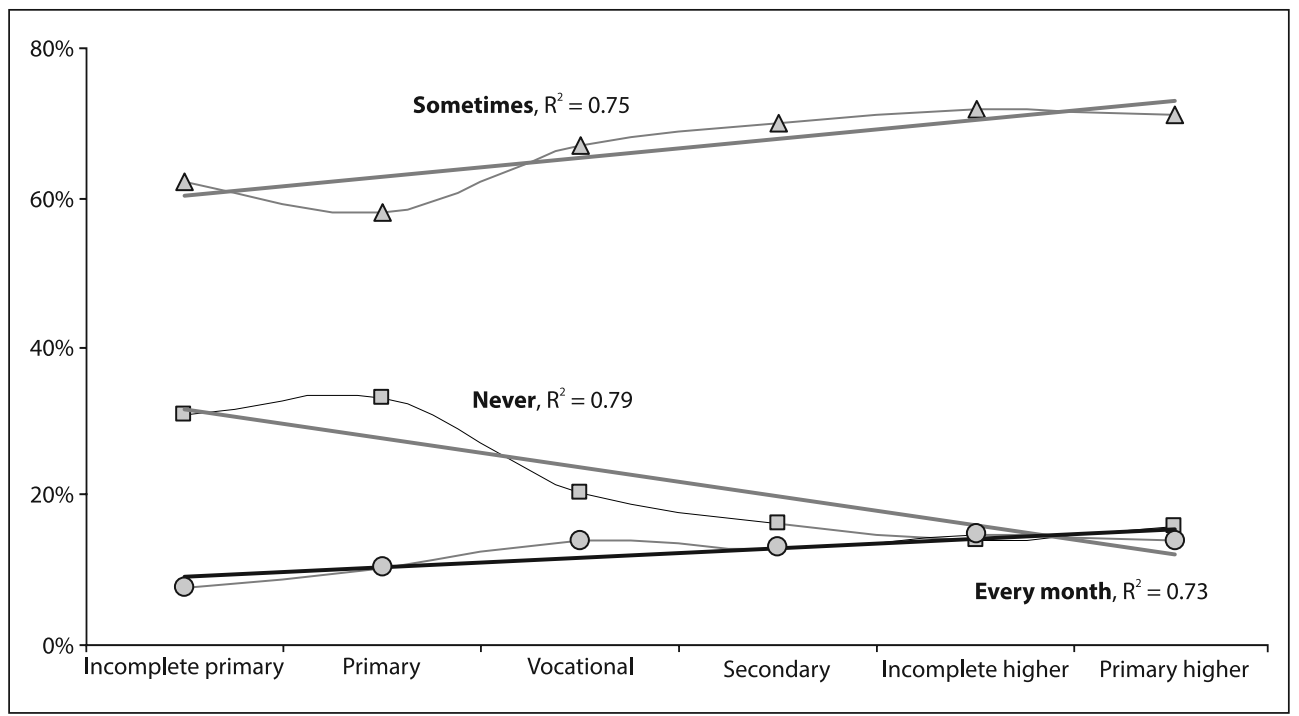

Figure 1. Changes in the proportion of women who perform breast self-examination as a function of educational level

\section{Impact of selected risk factors on the frequency of breast self-exams}

In the group of 2396 women who reported a family history of breast cancer, only $15.4 \%$ declared that they performed self-exams every month; the corresponding figure for respondents without a family history of the disease stood at $13.7 \%$.

Only $14.9 \%$ of women who had been taking hormonal medication in the previous five years declared that they examined their breasts on a regular basis; the corresponding figure for other respondents stood at $13.8 \% .17 .3 \%$ of women with breast ailments reported regular self-exams, as compared to $12.9 \%$ of respondents without similar complaints (Tab. III).

\section{Discussion}

Essential health-promoting behaviors that form part of secondary breast cancer prevention include breast selfexams and mammography screening. Regular check-ups enable the early detection of disease and demonstrate a sense of responsibility for one's own health.
The present study found that only one in seven women (14\%) in Lower Silesia examines her own breasts every month; $18 \%$ do not do it at all and $68 \%$ only every now and then. In a CBOS survey conducted in 2002 (i.e. before the implementation of the Population-Based Early Breast Cancer Detection Program) the proportion of women who declared that they examine their breasts regularly was twice as high (28\%), while the percentage of respondents who never did it was similar (20\%). It is worth noting that as many as $80 \%$ of the women in the CBOS survey said "yes" when asked: "Are you familiar with the breast self-exam, recommended by physicians as a method for the early detection of breast cancer?" [13]. The figure may suggest that most women have the requisite knowledge about breast cancer prevention but only few decide to put it into practice.

Regular monthly self-exams are recommended especially for women from high-risk families from the age of 18 onward [14]. The effectiveness of the method in cancer detection is limited due to its low sensitivity and specificity [15], but also due to the low frequency with which it is

Table II. Frequency of breast self-exams as a function of educational level

\begin{tabular}{|c|c|c|c|c|c|c|c|c|}
\hline \multirow[t]{2}{*}{ Variable } & \multicolumn{2}{|c|}{ Every month } & \multicolumn{2}{|c|}{ Sometimes } & \multicolumn{2}{|c|}{ Never } & \multicolumn{2}{|c|}{ Total } \\
\hline & $\mathrm{n}$ & $\%$ & n & $\%$ & $\mathrm{n}$ & $\%$ & n & $\%$ \\
\hline Incomplete primary & 8 & 7.2 & 69 & 62.2 & 34 & 30.6 & 111 & 0.3 \\
\hline Primary & 244 & 10.1 & 1405 & 58.4 & 758 & 31.5 & 2407 & 7.4 \\
\hline Vocational & 631 & 13.3 & 3124 & 65.9 & 989 & 20.8 & 4744 & 14.5 \\
\hline Secondary & 2056 & 14.1 & 10158 & 69.4 & 2409 & 16.5 & 14623 & 44.8 \\
\hline Incomplete higher & 292 & 14.9 & 1391 & 71.2 & 271 & 13.9 & 1954 & 6.0 \\
\hline Higher & 1077 & 14.3 & 5300 & 70.4 & 1151 & 15.3 & 7528 & 23.1 \\
\hline Data unavailable & 204 & 16.2 & 806 & 64.0 & 249 & 19.8 & 1259 & 3.9 \\
\hline Total & 4512 & & 22253 & & 5861 & & 32626 & 100 \\
\hline
\end{tabular}


Table III. Impact of risk factors and alarming symptoms on the frequency of breast self-exams

\begin{tabular}{|c|c|c|c|c|c|c|c|c|c|c|c|c|}
\hline \multirow{3}{*}{$\begin{array}{l}\text { Exposure to a risk } \\
\text { factor }\end{array}$} & \multicolumn{12}{|c|}{ Risk factors and alarming symptoms } \\
\hline & \multicolumn{4}{|c|}{ Family history of breast cancer } & \multicolumn{4}{|c|}{$\begin{array}{l}\text { Use of hormonal medication } \\
\text { in previous } 5 \text { years }\end{array}$} & \multicolumn{4}{|c|}{ Breast ailments } \\
\hline & $\mathrm{L}_{\mathrm{K}}$ & $\%$ & $\mathrm{~L}_{\mathrm{KS}}$ & $\%$ & $\mathrm{~L}_{\mathrm{K}}$ & $\%$ & $\mathrm{~L}_{\mathrm{KS}}$ & $\%$ & $\mathrm{~L}_{\mathrm{K}}$ & $\%$ & $\mathrm{~L}_{\mathrm{KS}}$ & $\%$ \\
\hline YES & 2396 & 7.3 & 369 & 15.4 & 2042 & 6.3 & 304 & 14.9 & 6825 & 20.9 & 1178 & 17.3 \\
\hline NO & 30230 & 92.7 & 4143 & 13.7 & 30584 & 93.7 & 4208 & 13.8 & 25801 & 79.1 & 3334 & 12.9 \\
\hline Difference (YES - NO) & & & & 1.7 & & & & 1.1 & & & & 4.4 \\
\hline Total & 32626 & 100 & & & 32626 & 100 & & & 32626 & 100 & & \\
\hline
\end{tabular}

$L_{K}$-number of women with the risk factor; $L_{K S}$-number of women who perform breast self-exams every month

practiced [16]. Despite these shortcomings, women should be taught breast exam techniques and encouraged to use them on a regular basis, so as to increase their appreciation and sense of responsibility for their own health.

The present study found that self-exam frequency significantly depended on age and educational level. Younger women were much more likely to examine their own breasts, and the proportion of those who never did considerably increased with age. A similar pattern was observed for education: the higher the level achieved, the greater the proportion of women who regularly examined their breasts; the lowest frequency was observed among respondents with primary and incomplete primary schooling. On average, one in three women with the corresponding educational level never examined her breasts, as compared to one in five and one in six for women who have completed vocational training and graduated from high school, respectively. These findings are consistent with the results of a study on 1000 Polish breast-cancer patients conducted in 2011 [17], which likewise reported a significantly higher frequency of regular breast self-exams among younger and better educated women.

Despite the high incidence and mortality rates of breast cancer, its etiology has not yet been fully explained. However, a number of risk factors have been identified, such as a history of breast cancer among close relatives and the prolonged use of hormonal medication. The present study assessed the impact of these risk factors on the frequency of regular breast self-exams. $7.3 \%$ of respondents reported a family history of breast cancer; however, only one in six or seven women from the group (15.4\%) declared that she examined her breasts every month. The figure was comparable to that for women without any family history of the disease (13.7\%). A similar pattern was observed for women who had taken hormonal medication within five years prior to the study. Only $14.9 \%$ reported regular self-exams, as compared to a similar figure among those who had not taken any hormonal medication (13.8\%). One in five (20\%) women reported the presence of breast ailments or lesions. The proportion of those who declared they examined their breasts regularly (17.3\%) was higher than the corresponding figure for women free from similar complaints (12.9\%). It seems that the presence of breast ailments and lesions has a significant impact on the regularity of breast self-exams. It is alarming, however, that a family history of breast cancer and the prolonged use of hormonal medication do not translate into a rise of cancer alertness and greater frequency of breast self-exams among respondents. This suggests a basic lack of awareness of the risk factors of the disease and the important role of self-exam in its secondary prevention. It is likely that the greater regularity of self-exams among women with breast ailments stemmed from the associated pain and discomfort rather than increased cancer awareness.

\section{Conclusions}

1. Age and education have a significant impact on the frequency of breast self-exams. Younger and better educated women perform them significantly more often.

2. A family history of breast cancer and the use of hormonal medication do not seem to have a significant impact on the frequency of self-exams. This may suggest a lack of awareness of the risk factors of the disease and the role of self-exams in its secondary prevention.

3. A presence of breast ailments or lesions has a significant impact on the frequency of breast self-exams; this correlation, however, seems to stem from the associated pain and discomfort rather than increased cancer awareness.

Conflict of interest: none declared

Elżbieta Garwacka-Czachor, MD, PhD

Lower Silesian Oncology Center in Wrocław

PI. Hirszfelda 12, 53-413 Wrocław, Poland

e-mail:garwacka.e@dco.com.pl

Received: 11 July 2016

Accepted: 24 Oct 2016 


\section{References}

1. Dyzmann-Sroka A, Marcinkowski JT, Kubiak A et al. Kto powinien zajmować się promocją skryningowego Populacyjnego Programu Wczesnego Wykrywania Raka Piersi? Probl Hig Epidemio/ 2009; 90:621-626.

2. Didkowska J, Wojciechowska U. Nowotwory złośliwe w Polsce w 2013 roku. Available at: http://onkologia.org.pl/wp-content/uploads/ BIUL2013.pdf. (accessed: 10.04.2016).

3. Boyle $\mathrm{P}$, Autier P, Bartelink Het al. European Code Against Cancer and scientific justification: third version (2003). Ann Oncol 2003; 14: 973-1005.

4. Wronkowski Z. Zapobieganie i wczesne wykrywanie nowotworów. Warszawa: Polski Komitet Zwalczania Raka; 2000.

5. Woynarowska B. Edukacja zdrowotna. Warszawa: Wydawnictwo Naukowe PWN; 2012

6. Kordek R, Piekarski J.Wczesna wykrywalność nowotworów. In: Kordek R (ed.) Onkologia. Podręcznik dla studentów i lekarzy. Gdańsk:Via Medica; 2007, pp. 67-70.

7. Żołnierczuk-Kieliszek D. Zachowania zdrowotne i ich związek ze zdrowiem. In: Kulik TB, Latalski M (ed.) Zdrowie publiczne. Lublin: Czelej; 2002, pp. 75-77.

8. Jokiel M. Społeczne aspekty wczesnego wykrywania raka piersi po wprowadzeniu w Polsce skryningów populacyjnych. Przegl Epidemiol 2009; 60: 445-449.

9. US PSTF. Screening for breast cancer: U.S. Preventive Services Task Force recommendation statement. Ann Intern Med 2009; 151: 716-726.
10. Hackshaw AK, PaulEA. Breast self-examination and death from breast cancer: a meta-analysis. Br J Cancer 2003; 88: 1047-1053.

11. Knutson $D$, Steiner $E$. Screening for breast cancer: current recommendations and future directions. Am Fam Physician 2007; 75: 1660-1666.

12. President of the National Health Fund. Załacznik nr 4 do Zarzadzenia Nr 86/2005 z dnia 13 października 2005 r. Prezesa Narodowego Funduszu Zdrowia w sprawie zatwierdzenia do realizacji profilaktycznych programów zdrowotnych. Available at: http://www.nfz.gov.pl/new/?katnr=3\&dzialnr=12\&artnr=1750 (accessed: 01.02.2016).

13. CBOS. Kobiety o profilaktyce raka piersi i raka szyjki macicy. Komunikat z badań. CBOS BS/57/2002. Available at: http://www.cbos.pl/SPISKOM. POL/2002/K_057_02.PDF (accessed: 25.02.2016).

14. Jassem J, Krzakowski M, Bobek-Billewicz B et al. Rak piersi. In: Krzakowsk $M$ et al. (ed.) Zalecenia postępowania diagnostyczno-terapeutycznego w nowotworach złośliwych. Warszawa: Polskie Towarzystwo Onkologii Klinicznej, 2013.

15. Thomas DB, Gao DL, Ray RM et al. Randomized trial of breast self-examination in Shanghai: final results. J Nat/ Cancer Inst 2002; 94: 1445-1457.

16. Łepecka-Klusek C, Jakiel G, Krasuska ME et al. Breast self-examination among Polish women of procreative age and the attached significance. Cancer Nurs 2007; 30: 64-68.

17. Grodecka-Gazdecka S, Zaborek P, Didkowska J et al. Uwarunkowania opóźnień w diagnostyce i terapii kobiet chorych na raka piersi w Polsce związane z postawami chorych. Nowotwory 2013; 63: 286-294. 